\title{
An Unfulfilled Expectation: Britain's Response to the Question of Korean Independence, 1903-1905
}

Euy Suk Kwon*

\section{Introduction}

This article aims to demonstrate how Britain responded to the question of the independence of Korea between 1903, when Russo-Japanese tension over Korea steeply escalated, and 1905, when Korean was made a Japanese protectorate after the Russo-Japanese War. In 1903, Northeast Asia fell into turmoil since Russia adopted a new expansionist policy towards Manchuria and Korea. Japan, who had regarded Korea as the "lifeline" to their national security, was alarmed by Russia's advance towards the Korean peninsula. The steeply escalated tension between Russia and Japan eventually resulted in the Russo-Japanese War of 1904. After a series of successful military campaigns in Manchuria and the Korean seas, Japan obtained international recognition of their special interest in Korea by the Treaty of Portsmouth, which was signed on 5 September 1905, and it eventually led to the Japanese establishment of a protectorate over Korea.

Korea was also aware of the rise of the Russo-Japanese rivalry over the country. In fear of losing its independent status, the Korean government

* Ph.D. Candidate, School of East Asian Studies, University of Sheffield, Sheffield, United Kingdom 
vigorously tried to maintain the integrity of Korea by means of diplomacy. Britain was one of the most important Western powers for Korea since the Anglo-Korean Treaty of 1883 . Since Korea became completely independent from Chinese influence in 1895, Britain favoured the idea of Korean independence because it was desirable for British strategic and commercial interests in the region. However, by the time around the Russo-Japanese War, Britain became very sceptical of the independence of Korea and hence concurred with Japan's protectorate scheme.

First, this article examines how Britain reacted to two main Korean questions that had been caused by the escalation of the Russo-Japanese tension in 1903; one is the Yongampo Incident, which sparked RussoJapanese conflict over the Yalu River basin; and the other is Kojong's proposal for the neutralisation of Korea in event of war. Secondly, it explains why Britain supported Japan's Korea policy, since the country was occupied by Japan immediately after the outbreak of the war. Thirdly, it explores why Britain ignored Korea's appeals for the independence of the country.

\section{Anglo-Korean Relations before the Outbreak of the Russo-Japanese War}

\section{The Rise of Russo-Japanese Tension}

Russo-Japanese rivalry over Korea started to emerge in 1895, when Japan defeated China in the First Sino-Japanese War of 1894-5. On 17 April 1895, both parties signed the Treaty of Shimonoseki, which stipulated the complete independence of Korea, the cession of Taiwan and the Liaodong Peninsula to Japan. However, Japan had to abandon the concession of the Liaodong Peninsula due to international pressure from the Triple Intervention of Russia, France and Germany. The Korean Court, who worried about the expansion of Japanese influence, was impressed by Russia's influence and then facilitated Russia to consolidate their position on the 
Korean Peninsula to check Japanese advances. Immediately, RussoJapanese confrontation intensified through several events, including the Japanese murder of Queen Min in October 1895 and Kojong's asylum at the Russian Legation in the following year.

Tension between Japan and Russia escalated when Russia occupied Manchuria in justification of protecting their nationals and properties during the Boxer Rebellion of 1900. When Japan asked Britain to confront together against the Triple Intervention five years ago, Britain rejected any intervention in the matter because Japan's withdrawal from the Liaodong Peninsula would only damage Japan's position in Korea, not Britain's interests in China. ${ }^{1}$ Nevertheless, the Russian occupation of Manchuria was an immense threat to the integrity of China, which was crucial for Britain's interests. Immediately after the Russian seizure, Britain signed the "Yangtze Agreement" with Germany and Japan in October 1900 and attempted to stop Russia's further advances. ${ }^{2}$

In response to their calls for the withdrawal of troops, on 8 April 1902, the Qing Court and the Russian Government signed a convention regarding Manchuria and set a three-stage evacuation plan. According to the plan, the first stage of the Russian evacuation took place from the southwestern part of Mukden by October 1902, followed by next evacuation stage to be conducted by April 1903. ${ }^{3}$

Russia's approach to Northeast Asia dramatically changed when Russian Finance Minister Sergei Witte, who preferred a moderate policy towards the region, lost his position and power in August 1902. The Russian Court and government decided to adapt an expansionist policy towards the region and Aleksandr Mikhailovich Bezobrazov was the key

1 Choi Moon-Hyung, Han'gukŭl Tullŏssan Chegukchuŭi Yŏlgangŭi Kakch'uk (Imperialist Powers' Rivalry over Korea) (Seoul: Chishiksanŏpsa, 2001), 148.

2 John White, Transition to Global Rivalry: Alliance Diplomacy and the Quadruple Entente, 1895-1907 (Cambridge: Cambridge University Press, 1995), 12-5.

3 Ian Nish, The Origins of the Russo-Japanese War (New York: Longman, 1985), 139-44. 
architect. He believed that it would be a catastrophic mistake for Russia if they withdrew from Manchuria and even asserted that they should not only consolidate their dominance in Manchuria, but also expand its sphere of influence upon Korea. ${ }^{4}$

Bezobrazov was particularly interested in P'yŏngan-do that neighboured Manchuria along the Yalu River. To gain their foothold in the region, Russia firstly attempted to transfer a concession of railway construction between Seoul and Ǔiju from a French national to a Russian firm. The latter was a traditional hub of Sino-Korean land trade that was located on the lower basin of the Yalu River. Although the railway concession was granted to a French national in 1896, the construction did not start until April 1902 and then was repeatedly suspended and resumed. Thus, on 16 February 1903, Russian Minister Evgenii Stein made an inquiry about the transfer of the French railway concession to a Russian national. ${ }^{5}$ However, the Russian proposal was immediately opposed by Japanese Minister Hayashi Gonsuke, who coerced that the Japanese government would demand great privileges if the railway concession was granted to Russia. ${ }^{6}$ Therefore, under Japanese pressure, Korean Foreign Minister Cho Byung-Sik rejected the Russia offer on the ground that the railway concession had been exclusively granted to the French government. $^{7}$

While attempting to take over the French railway concession, Russia also tried to secure their lumber concession on the Korean bank of the Yalu River that had been granted in 1896. In April 1903, Russia decided to exercise their timber concessions on the Korean bank of the Yalu River

4 Seung-Kwon Synn, The Russo-Japanese Rivalry over Korea, 1876-1904 (Seoul: Yukphubsa, 1981), 332-6; Nish, The Origins of the Russo-Japanese War, 168-74.

5 Foreign Office Document (FO) 405/137, Jordan to Lansdowne, 24 February 1903, The National Archives (hereafter, "TNA"), 6.

6 FO 405/137, Hayashi to Korean Minister for Foreign Affairs, 18 February 1903, TNA, 8-9.

7 FO 405/137, Korean Minister for Foreign Affairs to Russian Charge d'Affaires, 20 February 1903, TNA, 9. 
and founded the Russian Lumbering Company to take charge of the concession. The main purpose of the concession was closely related to Russia's new jingoist policies, such as the cancellation of the second evacuation of Russian troops, which should have taken place on 8 April $1903 .{ }^{8}$ Former Russian Minister to Seoul N. G. Matiunin argued that Russia should fortify the Yalu River to defend its concessions in Manchuria and Korea from possible invasion from the Japanese side. ${ }^{9}$

\section{Britain's Response to the Yongampo Crisis of 1903}

The British Legation in Seoul was already aware of Russia's claim for lumber concessions along the Yalu River. They also noticed that a Japanese company merged with the Chinese I-Sheng Company, which had acquired an agreement to exploit the forests in the lower basin of the Yalu River, and claimed the same right as Russia's in the same area. ${ }^{10}$ The British Legation continuously monitored the development of the concession conflict between Russia and Japan suspecting Russia's intention but neither London nor the legation in Seoul took direct action to interfere.

However, before long in May 1903, the British Legation was alarmed when a French national was granted a mining concession in Changsong, P'yŏngan-do, which was very close to the Russian-timbering forests near the Yalu River. British Minister John Jordan believed that the choice of the mine was made on the basis that it was very accessible to the Russian timber concession and Uiju. Jordan saw this decision as a politically significant action to strengthen a foothold of the Russo-French alliance along

8 Kang Young-Shim, "Kuhanmal Rŏshiaŭi Samnimigwŏnhoektŭkkwa Samnimhoesaŭi Ch'aebŏlshilt'ae (Russia's Forest Concession and Deforestation in the Late Yi Dynasty)," Ihwasahakyŏn'gu 17·18 (October 1988): 493-5.

9 Park Chong-hyo, Rǒsia Kungnip Munsǒ Pogwanso Sojang Han'guk Kwallyŏn Munso Yoyakchip (The Summary of Korea-Related Documents at the Russian National Archives) (Seoul: Korea Foundation, 2002), 230.

10 FO 405/137, Jordan to Lansdowne, 6 May 1903, TNA, 18a-18c. 
the Yalu River. ${ }^{11}$ Thus, Jordan argued that the Korean government should be advised to open the Yalu River to foreign merchants, not only to prevent Russia and France from enjoying exclusive privileges in the region, but also to facilitate foreign trade between the ports along the Yalu River and those on the Shantung Peninsula. ${ }^{12}$

Moreover, by the end of May 1903, the British Legation in Seoul noticed that the Russian company had already started to establish houses and workshops at Yongampo, a small port at the mouth of the Yalu River. The Korean government argued to the Russian Legation that such buildings should not be constructed until the full-scale survey of the Yalu River basins had been undertaken by the Korean and Russian authorities in accordance with the timber concession agreement of 1896. Nevertheless, the Russian Legation was reluctant to take any responsibility for the matter and argued that it should be discussed between the Korean government and the Russian timber company. ${ }^{13}$ Jordan and British Minister to Japan Claude MacDonald were also aware that approximately 40 Russians and 100 Chinese workers were present at Yongampo with a small number of Russian guards. ${ }^{14}$ At this point, British Legations in Korea and Japan believed that a Russian presence at Yongampo was not a significant threat to the integrity of Korea.

However, when the British legation in Seoul received a report by E. Laporte, a French national and the commissioner of the Korean Customs, on his visit to the Yalu River, they realised that Russia had been seizing Yongampo on a larger scale than expected. Laporte stated that 50 Russians and 200 Chinese workers were already present at Yongampo. The report also mentioned that Russians had purchased approximately 50 acres of land in the best locations and enclosed it with a mud wall. ${ }^{15}$ Fur-

11 FO 405/138, Jordan to Lansdowne, 19 May 1903, TNA, 2.

12 FO 405/137, Jordan to Lansdowne, 25 May 1903, TNA, 15.

13 FO 405/138, Jordan to Lansdowne, 3 June 1903, TNA, 13-4.

14 FO 405/138, MacDonald to Lansdowne, 11 June 1903, TNA, 18.

15 FO 405/138, Report by M. Laporte, TNA, 39-40. 
thermore, it was reported that a large number of Chinese mounted bandits were hired by Russian officers as 'private bodyguards' in order to protect the Russian concessions along the Yalu and Tumen rivers. ${ }^{16}$ Jordan reached a conclusion that "the Russian Timber Concession is probably only a screen to cover ulterior political designs and to extend the policy which is being pursued in Manchuria to the adjacent portions of Korea." 17

Both the Japanese and British governments believed that any direct confrontation against Russia would complicate the current problem. Hence, they decided to exert their pressure upon Kojong to open the Yalu River to international commerce. ${ }^{18}$ In his audience with Kojong on 15 July, Jordan tried to persuade Kojong to open the Yalu River on two grounds; commercial and political. Jordan pointed out that the river was already being used for a large scale of foreign trade, which could have been an additional source of the tariff revenues if the Korean government opened the river to foreign merchants. Meanwhile, Jordan also warned about Russia's territorial designs in Korea. He emphasized that Manchuria was falling into the hands of Russians since Russia had successfully gained a firm footing and expanded influence within the region. Jordan argued that Korea would be turned into "the state of tutelage" by a similar process of what had happened in Manchuria unless it was stopped by opening the Yalu River to international trade. ${ }^{19}$

In the audience, Kojong assured Jordan that the Ministry of Foreign Affairs would take the question into account immediately. Nevertheless, Jordan found that the Korean government did not hasten to open the river. In response to Jordan's continuous requests, the Korean Ministry of Foreign Affairs replied that the opening procedure would take a long time

16 FO 405/138, Tseng Ch'i to Hsu, 8 May 1903, TNA, 34-5.

17 FO 405/138, Jordan to Lansdowne, 24 June 1903, TNA, 39.

18 Hyun Kwang-Ho, “Taehanjegukki Yongamp'osagŏne Taehan Chuhanilbon'gongsaŭi Taeŭng (A Counterplan of the Japanese Ministers to the Great Han Empire for Yongampo Incident)," Inmunhakyŏn'gu 34, no. 1 (April 2007): 258-61.

19 FO 405/138, Jordan to Lansdowne, 17 July 1903, TNA, 84. 
due to surveys to be undertaken before the opening of the river. ${ }^{20}$ Since then, Jordan continuously urged the opening of the river to the Korean Foreign Ministry, but he received no satisfactory answer from them. In September 1903, Jordan particularly mentioned Yongampo would be the most suitable and convenient port for foreign trade but it was again ignored by the Korean Foreign Ministry. ${ }^{21}$ In October 1903, Jordan and Japanese minister Hayashi jointly requested the opening of the river again to the Korean government. ${ }^{22}$ Later in November 1903, even the United States joined Japan and Britain to exert pressure upon the Korean government for the opening of Yongampo. ${ }^{23}$ Still, Kojong and the Korean government hesitated to open the port to foreign trade until the RussoJapanese War broke out and Seoul was occupied by Japanese troops and the Russian Legation withdrew from the country. ${ }^{24}$

Korea's reluctance to open Yongampo might stem from Kojong's expectation that the strengthened influence of Russia in the country would check the political and commercial penetration of Japan. However, the delayed opening of the port was not a measure to counterbalance Japanese influence since Russians revealed their obvious ambition in Korea by fortifying Yongampo without any consent from the Korean government. ${ }^{25}$ Rather, Kojong was waiting to see the result of negotiation between Russia and Japan, which had started in August 1903. Yet, Japan wanted Russian recognition of Japan's special influence in Korea while Russia only wished to acknowledge Japan's influence in Korea south of the $39^{\text {th }}$ paral-

20 Yŏngan (England Document) vol.2, Yi Chung-Ha to Jordan, 21 July 1903, Kuhankuk Oekyomunsŏ (The Deplomatic Documents in the Late Yi Dynasty) vol. 14, (Seoul: Korea University, 2010), 574.

21 Yŏngan vol. 2, Jordan to Yi Chung-Ha, 4 September 1903, 582.

22 FO 405/139, Jordan to Lansdowne, 13 October 1903, TNA, 21.

23 FO 405/139, Jordan to Lansdowne, 10 November 1903, TNA, 62.

24 Hyun, "Taehanjegukki Yongamp'osagŏne Taehan Chuhanilbon'gongsaŭi Taeŭng," 261-4.

25 Suh Young-hee, Taehanjegung Chŏngch'isa Yŏn'gu (The Political History of the Korean Empire) (Seoul: Sŏuldaehakkyo Ch'ulp'anbu, 2005), 134-44. 
lel. Therefore, both governments failed to reach an agreement and the Korean government missed an opportunity to open Yongampo by their own decision.

\section{The Question of Korean Neutrality in Event of War}

While taking a very cautious approach amid Russo-Japanese tension over Yongampo, Kojong was willing to gain the international recognition of the neutrality of Korea before the outbreak of war between both countries. One of Kojong's key foreign policies was to gain international recognition of Korean neutrality. Kojong wanted to achieve the neutralisation by guarantee of Western powers, especially the United States, and continuously requested American ministers to recognise Korean neutrality. In 1900, Kojong sent Cho Byung-Sik to Japan to discuss Japan's support for the neutrality of Korea. However, such attempts eventually failed because the United States was not willing to engage in Korean affairs while Japan was more interested in a Japan-Korea alliance rather than the neutralisation of Korea.

Other foreign powers also considered the idea of Korean neutrality. In 1896, London proposed the recognition by Japan, China, Russia and Britain of Korean neutrality but soon abolished the proposal because Britain had no desire to take a leading role. ${ }^{26}$ In 1901, the Russian government suggested the neutrality of Korea to Japan and even invited the United States to secure a neutrality deal in 1902 . Yet, Japan saw this offer as a surrender of Japan's established interest in Korea to the Russian side. The United States was also reluctant to engage with foreign powers and thus these powers failed to reach an agreement on the neutrality of Korea. ${ }^{27}$

26 Ian Nishi, The Anglo-Japanese Alliance: The Diplomacy of Two Island Empires, 1894-1907 (Connecticut: Greenwood Press, 1976), 43-4.

27 Seung-Young Kim, "Russo-Japanese Rivalry Over Korean Buffer at the Beginning of the 20th Century and its Implications," Diplomacy \& Statecraft 16, no. 4 (December 2005): 632-6. 
In 1903, as tension rose between Russia and Japan, Kojong retried to secure the international recognition of the neutrality of Korea. First, Kojong wanted to improve Korea's relationship with Britain. Kojong was furious at Britain when the Anglo-Japanese Alliance was signed in 1902. Kojong interpreted the alliance as Britain's consent to Japan's special interest in Korea. In an audience with Jordan, however, Kojong apologized for his misunderstanding of the Anglo-Japanese Alliance. He particularly mentioned Article 1 of the alliance, which stipulated the recognition of the independence of China and Korea, and showed his belief that Britain would make efforts to support the integrity of Korea. ${ }^{28}$ In August 1903, Kojong proposed the neutralisation of Korea to Russian and Japanese governments in case of any hostile event between two parties. ${ }^{29}$ Nonetheless, Japan declined the Korean offer on the ground that it would cause a misunderstanding as if Japan's aggression were very likely. ${ }^{30}$

On 21 January 1904, just before the outbreak of the Russo-Japanese War, with assist from the French Legation in Seoul, Korea declared the maintenance of neutrality in event of war to European powers, the United States and Japan. Japan and Russia, two belligerents, declined to accept the declaration because Korea would inevitably become a main battlefield. On the other hand, other Great Powers acknowledged the declaration of Korean neutrality. Kojong and the Korean Government were so encouraged by the wide acceptance of their neutrality declaration and relieved that the country would not be caught up in the upcoming war. Kojong even intended to turn this wartime declaration into permanent neutrality and hence ordered his government to consult with the French Legation for procedures required. ${ }^{31}$

Britain was one of the Great Powers that had recognised Korea's neu-

28 FO 405/138, Jordan to Lansdowne, 25 July 1903, TNA, 97-8.

29 FO 405/139, Jordan to Lansdowne, 26 August 1903, TNA, 8.

30 FO 405/139, Jordan to Lansdowne, 12 October 1903, TNA, 75.

31 Hyun Kwang-Ho, Taehanjegugŭi Taeoejŏngch'aek (The Foreign Policy of the Korean Empire) (Seoul: Sinsǒwŏn, 2002), 121-2. 
trality declaration. While welcoming Korea's announcement of its neutrality, Britain also urged the Korean government to neutralise Russia's exclusive privileges on the Yalu River, especially the Russian-seized Yongampo, in accordance with the principle of their neutrality declaration. Nevertheless, the Korean Government seemed uninterested in hastening to open the river because the opening had been deliberately delayed by them for avoiding any suspicion that Korea would incline to either Russia or Japan. Once the Korean Government believed to have achieved the international recognition of Korea's wartime neutrality, the opening of the Yalu River could not be a priority any more, especially in comparison with permanent neutrality issues.

On the contrary, Jordan saw the opening of the Yalu River as proof of the Korean Government's commitment to maintain neutrality and he hence thought that the Korean Government were naïve to believe that the country would not suffer from a war between Russia and Japan on the false belief that both belligerents would have to respect Korean neutrality under international pressure. ${ }^{32}$ Jordan was convinced that the Korean Government should undertake extra measures if they wanted to remove other's suspicion of Korea pursuing a "Russophile" policy. Despite his expectation, Jordan had an impression that the Korean government, who was very satisfied with the international recognition of neutrality, would not open the Yalu River to foreign trade any time soon. His view was shared by the Japanese and American ministers who jointly requested the opening. ${ }^{33}$

It clearly shows why Korea's declaration of neutrality in case of war failed to gain Britain's support. Firstly, the declaration of Korean neutrality was not followed by the neutralisation of Russia's exclusive concessions in Korea. Yongampo was being fortified by Russians while violating the concession agreement with the Korean government. Nonetheless, even after announcing their neutrality, the Korean government did not

32 Hyun, Taehanjegugŭi Taeoejŏngch'aek, 122-3.

33 FO 405/146, Jordan to Lansdowne, 30 January 1904, TNA, 87. 
take further action to stop Russia's consolidation of their foothold on the Yalu River. Therefore, London was convinced that the Korean government neglected or even encouraged the expansion of Russian influence in the country. Secondly, the Korean government did not obtain the recognition of neutrality by Japan and Russia, two belligerents who would fight over Korea and thus the neutrality of Korea could not be guaranteed if either belligerent was willing to occupy Korea for strategic concerns during the war. Consequently, Britain and other foreign powers were not fully convinced to support the neutralisation of Korea by all means. At this point, Jordan rather believed that "a peaceful solution might place them under the political tutelage of Japan.",34

\section{Anglo-Korean Relations during the Russo-Japanese War, 1904}

1. British Pressure on the Korean Court after the Outbreak of the RussoJapanese War

On 8 February 1904, the Russo-Japanese War broke out with Japan's sudden raid against a Russian fleet at Port Arthur, even though the declaration of war was officially delivered two days later. On the same day, 3,000 Japanese troops landed at Chemulpo and headed for Seoul. As an ally of Japan, the British Legation in Seoul acted in co-operation with the Japanese Legation since the outbreak of the war. Firstly, British and Japanese representatives strongly urged Kojong to remain at the palace. On 7 February, Kojong contacted Jordan and asked if it would be possible for him to take refuge at the British Legation in case of war. In response, Jordan discouraged the idea of asylum at the British Legation. Instead, Jordan joined Hayashi and assured Kojong that his safety would not be affected by Japanese troops if he remained inside the palace.

Jordan's action fundamentally stemmed from Britain's traditional non-

34 FO 405/147, Jordan to Lansdowne, 1 February 1904, TNA, 46. 
intervention policy regarding Korea. Kojong already made similar attempts after the Japanese murder of Queen Min in 1895 and his asylum at the Russian Legation in 1896. Britain immediately rejected his suggestion in fear that they would be further engaged with Korean affairs that might eventually lead to confrontations with other foreign powers. His rejection to Kojong's proposal was in alignment with Japanese minister Hayashi's intention. Since thousands of Japanese troops were heading for Seoul, it was necessary for Japan to seize the capital of the country and place Kojong under their control. Jordan facilitated the Japanese advance by urging to the Korean Foreign minister that Korean troops should restrain from taking any action against Japanese troops "which might result in useless bloodshed". ${ }^{35}$ Therefore, Kojong had to give up the idea of seeking asylum at the British Legation and decided to rely upon the British government's good offices in accordance with the Anglo-Korean Treaty of $1883 .^{36}$

While the British Legation in Seoul took actions in cooperation with the Japanese Legation to exert pressure upon the Korean government, they also took a very cautious approach to avoid any direct confrontation with Russia. On 9 February, once Seoul fell under the de facto occupation of Japanese troops, Japan wanted to force the Russian Legation staff and guards to withdraw from Seoul. Japanese minister Hayashi believed that it would be more acceptable for the Russian minister if the withdrawal request was delivered not by him as a representative of the enemy but by the British minister. However, the Foreign Office in London did not want to interfere with the matter because they were concerned the British Legation would responsible for misrepresentation. Hence, instead of the British minister, the French Legation took charge of all arrangements for the evacuation of the Russian Legation from Seoul.

London was very concerned about "misrepresentation" because the proposed mediation might give a false impression that Britain was active-

35 FO 405/147, Jordan to Lansdowne, 1 February 1904, TNA, 46.

36 FO 405/146, Jordan to Lansdowne, 10 February 1904, TNA, 125. 
ly participating in this war. According to Article 2 of the Anglo-Japanese Alliance, Britain should remain neutral if Japan was involved in a war against Russia over Korea. Thus, if the mediation was regarded by Russia as active support for the Japanese side, it could lead Britain into a war against Russia and its ally France. The possibility of a conflict against France was greatly reduced by the signing of the Entente Cordiale on 8 April 1904, but generally Britain's Korea policy during the RussoJapanese War concentrated on helping Japan consolidate its control over Korea while avoiding any direct confrontation with Russia.

\section{Britain's Response to the Japan-Korea Treaty of 1904}

Immediately after the Japanese occupation of Seoul, Britain became aware of the signing of the Japan-Korea Treaty of 1904 on 23 February 1904. The Japan-Korea Treaty stipulated that the Korean government should be fully confident in the good will of Japan and adopt any advice by the Japanese government regarding administrative reforms; that the Japanese government would be allowed to utilise facilities and strategic points in Korea during a war against a hostile power threatening the integrity of Korea; and that both Korea and Japan would not come to an agreement with a third power that should be contrary to the terms of the Japan-Korea Treaty. Hayashi explained to Jordan that the Japan-Korea Treaty was merely a duplication of the Japanese proposal to Russia during pre-war negotiations in 1903, which had been rejected by the Russian government. ${ }^{37}$ Furthermore, Hayashi warned the Korean government that they should not engage the service of foreign advisors without his consent. $^{38}$

However, Britain noticed that the Treaty had not been voluntarily signed by the Korean government. Jordan was aware that Yi Yong-Ik, then Korean Finance/War Minister and a well-known anti-Japanese poli-

37 FO 405/147, Jordan to Lansdowne, 25 February 1904, TNA, 61-2.

38 Suh, Taehan Cheguk Chongch'isa Yon'gu, 188-200. 
tician, was sent to Tokyo under pressure from the Japanese Legation because he had rejected the signing of the agreement. Moreover, Jordan believed that the agreement, which had authorised Japan to intervene in Korea's domestic affairs and to utilise Korean facilities for Japanese troops, intended to violate the neutrality of Korea. Despite such circumstances and the nature of the agreement, Jordan did not raise any question regarding the Japanese violation of the Korean neutrality. He believed that Korea was incapable to defend the integrity of the country on its own and thus eventually Korea "would be obliged to act at the dictation of the belligerent power which first occupied her capital." 39 From Jordan's point of view, the violation of the neutrality of Korea was inevitable since the Korean government failed to secure it by diplomacy or military means.

Therefore, Jordan refrained from intervening in the neutrality issues when Russia warned that Korea would be regarded as a belligerent nation if Japan received any support from Koreans during the war. In response, Hayashi simply suggested that the Korean government should instruct their provincial governors to ignore any communication from Russia. ${ }^{40}$ On 20 May, the Korean Government inclined to Japan when Kojong announced the abolition of all treaties and agreements with Russia, including the Russian timber concession of 1896. It was in accordance with the advice of the Japanese Government, who emphasised the significance of Korean co-operation during the war. ${ }^{41}$ Although it was another step to undermine the neutrality of Korea, the British Legation simply acknowledged the abolition of the treaties with Russia and avoided any intervention in it. Britain's connivance at the Japanese control over Korean diplomacy facilitated Japan's consolidation of its influence within the country.

39 FO 405/147, Jordan to Lansdowne, 25 February 1904, TNA, 61-2.

40 FO 405/148, Jordan to Lansdowne, 15 March 1904, TNA, 19.

41 Suh, Taehan Cheguk Chongch 'isa Yon'gu, 203-4. 


\section{Japan's Introduction of Administrative Reforms}

Since Japan successfully took control of the Korean court and government, Japan aimed to undertake administrative reforms in Korea. In June 1904, Japanese Foreign Minister Komura Jutarō informed British Minister to Japan Claude MacDonald that they would initiate reforms in Korea as soon as possible. Komura mentioned two main reasons for the reform scheme: debased coinage and concessions given by Kojong to foreign merchants. Komura accused Kojong of making a profit with the depreciation of coins by fixing a higher value than its actual worth. Komura and MacDonald agreed that the debased coinage would be seriously damaging to all nations trading with Korea. The second concern was Korean concessions given by Kojong to foreign firms. Komura complained that Kojong and the Korean Court gave these concessions "in the most foolish manner" and were concerned that the Korean government suffered the yielding of concessions. ${ }^{42}$ Japanese minister to Korea Hayashi Gonsuke also shared a similar view with MacDonald. MacDonald concurred with Hayashi's scepticism of Korea's self-strengthening and stated that the reform of Korea could be only done by two things, "to show strength and to use kindness." 43

According to Komura's argument, the administrative reform intended to solve the financial issues of the Korean government. Yet, since he criticised Kojong for exploiting the monopoly of the coinage and thoughtlessly giving concessions to foreigners, the main objective of the reform was obviously to restrain Kojong's political influence. In August 1904, Hayashi duly requested the reforms to Kojong, which included the reorganisation by a Japanese advisor of the national finance and the dismissal of foreign advisors currently hired by the Korean government. Additionally, Hayashi also requested that Durham White Stevens, then foreign advisor to the Japanese Legation to the United States in Washington,

42 FO 405/149, Jordan to Lansdowne, 24 June 1904, TNA, 30.

43 FO 405/149, Jordan to Lansdowne, 29 June 1904, TNA, 30-1. 
should be appointed as an advisor to the Korean Foreign ministry. ${ }^{44}$ Kojong was unhappy with the proposed appointment of Stevens. Therefore, Kojong privately told Jordan that he would prefer a British national as a foreign advisor and asked if he could intervene with Hayashi to make it happen. However, Jordan had no intention to pressure the Japanese minister on the matter and ignored Kojong's request. ${ }^{45}$

In addition to the administrative reforms, the Japanese government also requested the withdrawal of Korean legations abroad. ${ }^{46}$ Since the opening of the nation to the world in 1876, Kojong relied upon diplomacy to secure the independence of Korea and thus maintained overseas legations despite the cost. On the contrary, it was for a long time seen by the British legation as a waste of the national budget, which was already insufficient for the modernisation of the administration and military. Jordan believed it was a reasonable step to enhance the financial situation of the country and also assured that Japanese legations would successfully handle Korean overseas affairs. ${ }^{47}$ Jordan was particularly happy with Japan's assurance that James McLeavy Brown, a British national in charge of the Korean Customs, would not be affected by the proposed abolition of foreign advisors from the Korean government. ${ }^{48}$ Jordan believed that the Korean Customs was largely a British administration and that there would be no difficulty in the renewal of Brown's contract.

After the Yongampo Crisis of 1903, Britain was convinced that the Korean government would neglect or even allow the expansion of the Rus-

44 FO 405/149, Jordan to Lansdowne, 13 August 1904, TNA, 32-3.

45 FO 405/149, Jordan to Lansdowne, 14 August 1904, TNA, 33; FO 405/149, Lansdowne to Jordan, 15 August 1904, TNA, 33.

46 Suh, Taehan Cheguk Chongch 'isa Yon'gu, 200-4.

47 FO 405/149, Jordan to Lansdowne, 16 August 1904, TNA, 62-3.

48 Kim Won-Soo, "Ilbonŭi Taehanjegung Pohogukhwawa Yŏnggugŭi Taehanjŏngch'aek - Yŏngiltongmaenggwa Rŏilchŏnjaengŭl Chungshimŭro (British Policy toward Korea before and after Japan's Protectoration of Korea: Focused on the Anglo-Japanese Alliance and the Russo-Japanese War)," Han'guktongnibundongsayŏn'gu 51 (August 2015): 200-1. 
sian influence beyond Manchuria. Britain hence became very sceptical of the Korean government's capacity to self-strengthen or modernise its military and administration. Therefore, Britain agreed to facilitate Japan's occupation of the country and concurred with Japan's administrative reform. Moreover, Japan assured that the position of Brown would not be threatened even if administrative reform would enhance Japan's dominant position in the country. Overall it was a favourable decision for British interests in the country because the Japanese occupation would stop Russian penetration into Korea and the Korean Customs would remain under British influence.

\section{The Establishment of a Japanese Protectorate over Korea, 1905}

\section{Korea's Final Efforts to Secure British Support}

Since the middle of 1904, the Japanese government believed that they were unable to afford a long-term war due to excessive casualties and limited resources and sought a third-party mediator who would arrange a peace negotiation with Russia. Russia was unwilling to enter a peace conference despite their successive defeats in Manchuria and the Korean seas. However, since their unsuccessful campaigns caused internal turmoil and the Battle of Mukden caused severe casualties, Russia agreed to negotiate a peace treaty with the Japanese government through the mediation of United States President Theodore Roosevelt. Therefore, since February 1905 , Western newspapers started to report the progress of peace negotiations.

Yi Han-Eung, Korean Acting Minister to Britain in London, noticed that both Russian terms and Japanese terms included clauses that would severely affect the independence of Korea. Russian peace terms stated that "Korea to be placed under Japanese suzerainty" and Japanese peace terms stipulated the "recognition of Japan's influence in Korea as su- 
preme." 49 Since both parties would recognise Japan's suzerainty over Korea regardless of which side would win the war, the Korean government sought British intervention in the peace talks. With the Korean government's instruction emphasising that Britain would be the only power to "give weight in this matter," Yi Han-Eung contacted the British Foreign Office in London and asked for intervention in peace negotiations. He argued that the integrity of Korea was recognised in accordance with the Anglo-Japanese Alliance of 1902 and thus it should be respected since Japan was a signatory. ${ }^{50}$ However, Lord Lansdowne rejected any talk with Yi by stating that "any discussion of the terms of peace as affecting Korea would not, in my opinion, be likely to have any useful results at the present moment." 51

Yi Han-Eung once again requested the British Foreign Office for intervention in peace negotiations on 22 March but Lord Lansdowne limited himself to acknowledge the receipt of his memorandum on 1 April. Having failed to secure British support, on 12 May, Yi committed suicide in his bedroom to take responsibility for it. ${ }^{52}$ Despite Britain's reluctance, Kojong still wished to gain British support for the integrity of Korea. Immediately after Yi's suicide, Kojong instructed the Korean legation in Paris, France to take over the duties of the Korean legation in London. Nevertheless, such an attempt was soon stopped by Hayashi and Stevens. ${ }^{53}$ Once again, in June 1905, Kojong attempted to directly contact Jordan while avoiding the channel of the Korean Foreign Ministry, which was under the control of Hayashi and Stevens. He requested Britain's intervention in peace negotiations to guarantee the integrity of Korea that

49 FO 405/158. Yi Han-Eung to Lansdowne, 3 March 1905, TNA, 39-40.

50 FO 405/158. Yi Han-Eung to Lansdowne, 3 March 1905, TNA, 37-8.

51 FO 405/158, Lansdowne to Yi Han-Eung, 13 March 1905, TNA, 49.

52 Taeyeol Ku, "A Korean Diplomate in London: Yi Haneung and Anglo-Korean Relations," in Korean-British Relations, Yesterday, Today and Tomorrow: Essays in Celebration of the Centenary of Korean-British Diplomatic Relations, ed. Chong-wha Chung and J. E. Hoare (Seoul: Korean-British Society, 1984), 73-87.

53 FO 405/160, Jordan to Lansdowne, 20 May 1905, TNA, 2. 
had been stipulated in the Anglo-Japanese Alliance. Jordan declined the request by pointing out that the negotiations were being undertaken exclusively between Japan and Russia. ${ }^{54}$

It is worth noting that both Yi Han-Eung and Kojong argued that the independence of Korea should be respected in accordance with the Anglo-Japanese Alliance of 1902. At first, the Anglo-Japanese Alliance was regarded by Koreans as Britain's consent to Japan's superior position in the country, but soon the Korean government used Article 1 of the alliance, which stipulated the integrity of Korea, to justify Britain's assistance. They also believed that the independence of Korea would be maintained if the Anglo-Japanese Alliance and the Franco-Russian Alliance were checking each other. ${ }^{55}$ However, since the main objective of the alliance was to prevent Russian penetration into China and Korea, Britain had no intention to make a military and diplomatic commitment to secure the independence of Korea.

\section{British Agreement with the Japanese Protectorate Scheme}

As it became obvious that Japanese influence in Korea would be recognised by Russia, Japan started to discuss a protectorate scheme with the British government. In July 1905, Japanese prime minister Katsura Tarō pointed out to MacDonald that the main cause of the Russo-Japanese War was "the habit of the Emperor of Korea, of high Korean officials, of intriguing with foreign Powers, and of making arrangements and agreements in the most irresponsible manner." He thus argued that the power of the Korean emperor and ministers should be severely restricted "for the peace of the Far East and the future good government of Korea." 56 While Katsura emphasised the importance of the limitation of the Korean em-

54 FO 405/160, Jordan to Lansdowne, 19 June 1905, TNA, 10-1.

$55 \mathrm{Ku}$, "A Korean Diplomate in London: Yi Haneung and Anglo-Korean Relations," 73-6; Seung-Young Kim, "Russo-Japanese Rivalry Over Korean Buffer,” 629.

56 FO 405/160, MacDonald to Lansdowne, 31 July 1905, TNA, 50-1. 
peror's power, he also assured that such measures would not affect the treaty rights that foreign powers had been enjoying in Korea. Katsura confirmed that such privileges as consular jurisdiction and customs tariff would be dealt with through the same procedure as Japan's unequal treaty revision if they should be changed.

Japan's special rights in Korea was also acknowledged by the revised Anglo-Japanese Alliance of 1905. Because the United States and Britain were seen by some Koreans as the potential protectors of Korea due to "good offices" clauses in their treaties, it was important for Japan to convince Britain that a Japanese protectorate would be preferable. ${ }^{57}$ Britain also believed that the corrupt Korean government was incapable of maintaining its independence. ${ }^{58}$ Therefore, Britain agreed to acknowledge Japan's right to "take such measures of guidance, control and protection" in Korea. ${ }^{59}$ After the Treaty of Portsmouth was signed on 5 September 1905, the Japanese government once again revealed their intention to establish a protectorate over Korea. Lord Lansdowne consented to the protectorate scheme and assured that Britain would not oppose it. ${ }^{60}$

The Korean government was very concerned that the revised AngloJapanese Alliance had officially recognised Japan's right to make Korea a protectorate. Therefore, the Korean government revealed their dissatisfaction to the British Legation and argued that the new agreement was inconsistent with the Anglo-Korean Treaty of 1883 that had recognised Korea as an independent state. ${ }^{61}$ However, at this point, Jordan worried that even an acknowledgement of the receipt of the correspondence would lead to further protests from Kojong and thus he even refused to reply to

57 Seung-Young Kim, American Diplomacy and Strategy toward Kora and Northeast Asia, 1882-1950 and After (New York: Palgrave, 2009), 58-60.

58 Han Seung-Hoon, “Ǔlsanŭkyakŭl Chŏnhuhan Yŏnggugŭi Taehanjŏngch'aek (British Policy toward Korean around 1905 Convention)," Han'guksahakpo 30 (February 2008): 399-404.

59 Nish, The Anglo-Japanese Alliance, 320-2.

60 FO 405/160, Lansdowne to MacDonald, 26 September 1905, TNA, 55.

61 FO 405/161, Jordan to Lansdowne, 18 October 1905, TNA, 13. 
it. With Britain's consent, the Japan-Korea Protectorate Treaty was eventually concluded on 17 November 1905 and Jordan believed that the protectorate scheme could be justified by Japan's considerations for their own national security since it would prevent Korea from forming an alliance with such a potential enemy as Russia.

Britain concurred in the Japanese establishment of a protectorate over Korea on the basis that the Korean court and emperor had destabilised the regional order. Moreover, Japan's assurance to maintain foreign powers' treaties with Korea was also an important reason why Britain agreed with the protectorate plan. On 1 November 1905, Lord Lansdowne wanted to ensure that Britain's current treaties with Korea would remain undisturbed and he was satisfied when the Japanese government agreed with it. ${ }^{62}$ Even after the signing of the Protectorate Treaty, the Japanese government continuously assured that they would respect the open-door policy in Korea and that Korea's treaties with foreign powers would remain in effect. ${ }^{63}$

To sum up, Japan's establishment of a protectorate on Korea met Britain's expectations. First, since Kojong had destabilised the regional order by continuously inviting foreign powers to check Japanese penetration, the Japanese protectorate plan would prevent Russian advances towards the country. Secondly, Japan assured that Britain's treaty rights, which they had been enjoying since the Anglo-Korean Treaty of 1883, would be respected even if Korea became a Japanese protectorate. Britain was hence convinced that they would still maintain their commercial interest in the country thanks to the Japanese assurance.

62 FO 405/161, Lansdowne to MacDonald, 1 November 1905, TNA, 25; FO 405/161, Lansdowne to MacDonald, 9 November 1905, TNA, 28.

63 FO 405/161, MacDonald to Grey, 29 December 1905, TNA, 52. 


\section{Conclusion}

The article discussed Britain's responses to the Korean questions between 1903 and 1905, when Russo-Japanese tension reached its height. The Yongampo Crisis of 1903 was a decisive event that influenced Britain's view on the independence of Korea. Britain was concerned that Korea pursued pro-Russian policies that would seriously affect the opendoor principle in the same way as Russia did in Manchuria. On the other hand, Korea was more concerned about provoking Russia and Japan and hence they were reluctant to immediately neutralise Russia's exclusive concessions along the Yalu River. Therefore, when Kojong declared neutrality just before the outbreak of the Russo-Japanese War, Britain regarded it as nothing but a nominal announcement that would be neglected once either belligerent nation occupied Seoul.

In addition to it, British representatives in Northeast Asia shared the same opinion that Kojong consistently destabilised the regional order by intrigues with foreign powers and that they were incapable of modernisation due corruption. Thus, when Japan occupied Korea and introduced several reforms that placed the Korean government under Japanese control, Britain was convinced that it would be the most suitable measure for the maintenance of the regional order. Korea approached the British government for the support of the integrity of Korea in the name of the Anglo-Japanese Alliance. Nevertheless, because the main objective of the alliance was to prevent Russian expansion, Britain declined to help Korea and concurred with Japan's protectorate scheme.

Japan's establishment of a protectorate was desirable for Britain's strategic interests in the region too. It was a satisfactory deal for the British government because the Japanese government assured that Britain's existing treaties with Korea would remain undisturbed. Thanks to it, Britain was still able to enjoy such treaty rights as consular jurisdiction and customs tariff in Korea under Japanese protection. From the British perspective, Korea eventually failed to prove that they could modernise the country and thus Japan's plan to make Korea a protectorate was the most de- 
sirable policy for Britain to stabilise the regional order and to safeguard their commercial interests.

\section{References}

1. Choi, Moon-Hyung. Han'gukŭl Tullŏssan Chegukchuŭi Yŏlgangŭi Kakch'uk (Imperialist Powers' Rivalry over Korea). Seoul: Chishiksanŏpsa, 2001.

2. Han, Seung-Hoon. "Ǔlsanŭkyakŭl Chŏnhuhan Yŏnggugŭi Taehanjŏngch'aek (British Policy toward Korean around 1905 Convention)." Han'guksahakpo 30 (February 2008): 387-421.

3. Hyun, Kwang-Ho. Taehanjegugŭi Taeoejŏngch'aek (The Foreign Policy of the Korean Empire). Seoul: Sinsǒwŏn, 2002.

4. Hyun, Kwang-Ho. “Taehanjegukki Yongamp'osagŏne Taehan Chuhanilbon'gongsaŭi Taeŭng (A Counterplan of the Japanese Ministers to the Great Han Empire for Yongampo Incident)." Inmunhakyŏn'gu 34, no. 1 (April 2007): 247-72.

5. Kang, Young-Shim. "Kuhanmal Rŏshiaŭi Samnimigwŏnhoektŭkkwa Samnimhoesaŭi Ch'aebŏlshilt'ae (Russia's Forest Concession and Deforestation in the Late Yi Dynasty)." Ihwasahakyŏn'gu 17·18 (October 1988): 483-502.

6. Kim, Seung-Young. "Russo-Japanese Rivalry over Korean Buffer at the Beginning of the 20th Century and its Implications." Diplomacy $\&$ Statecraft 16, no. 4 (December 2005): 619-50.

7. Kim, Seung-Young. American Diplomacy and Strategy toward Kora and Northeast Asia, 1882-1950 and After. New York: Palgrave, 2009.

8. Kim, Won-Soo. "Ilbonŭi Taehanjegung Pohogukhwawa Yŏnggugŭi Taehanjŏngch'aek - Yŏngiltongmaenggwa Rŏilchŏnjaengŭl Chungshimŭro (British Policy toward Korea before and after Japan`s Protectoration of Korea: Focused on the Anglo-Japanese Alliance and the Russo-Japanese War)." Han'guktongnibundongsayŏn'gu 51 (Au- 
gust 2015): 187-215.

9. Ku, Taeyeol. "A Korean Diplomate in London: Yi Haneung and Anglo-Korean Relations." In Korean-British Relations, Yesterday, Today and Tomorrow: Essays in Celebration of the Centenary of Korean-British Diplomatic Relations, edited by Chong-wha Chung and James E. Hoare. Seoul: Korean-British Society, 1984.

10. Nish, Ian. The Anglo-Japanese Alliance: The Diplomacy of Two Island Empires, 1894-1907. Connecticut: Greenwood Press, 1976.

11. Nish, Ian. The Origins of the Russo-Japanese War. New York: Longman, 1985.

12. Suh, Young-hee. Taehanjegung Chŏngch'isa Yŏn'gu (The Political History of the Korean Empire). Seoul: Sŏuldaehakkyo Ch'ulp'anbu, 2005.

13. Synn, Seung-Kwon. The Russo-Japanese Rivalry over Korea, 18761904. Seoul: Yukphubsa, 1981.

14. White, John. Transition to Global Rivalry: Alliance Diplomacy and the Quadruple Entente, 1895-1907. Cambridge: Cambridge University Press, 1995. 
$<$ Abstract $>$

\section{An Unfulfilled Expectation: Britain's Response to the Question of Korean Independence, 1903-1905}

Euy Suk Kwon

This article examines Britain's response to the question of Korean independence amid Russo-Japanese rivalry between 1903 and 1905. Russo-Japanese tension reached its peak when Russians unilaterally seized and fortified Yongampo in 1903. Britain expected Korea to check the Russian penetration by opening Yongampo and the Yalu River to foreign commerce, but Korea delayed the opening until the country fell under Japanese occupation in March 1904. Korea's reluctance to open the river also made Britain suspect Korea's declaration of neutrality. Therefore, when the Russo-Japanese War broke out, Britain acted in cooperation with Japan when they forced Korea to accept Japanese control. Furthermore, since Korea failed to modernise the government, Britain believed that the country should be placed under the control of Japan. Although Kojong and the Korean government were seeking Britain's support for the integrity of Korea, Britain approved Japan's plan to make Korea a protectorate and tried to secure their commercial interest in the country.

Keywords: Anglo-Korean Relations; Kojong; Korea; Britain; British Foreign Policy; Korean Foreign Policy; Anglo-Japanese Alliance; Russo-Japanese War; Korean Independence; Korean Neutrality 


\section{〈국문초록〉}

\section{실현되지 않은 기대: 1903-1905년 한국 독립문제에 대한 영국의 대응}

권의석 (셰필드대 동아시아학과 박사과정)

본 연구는 러시아와 일본의 대결이 치열해진 1903년에서 1905년 사이 영국이 대한제국의 독립문제에 대해 어떻게 대응했는지 살펴본다. 러일간의 갈등은 1903 년 러시아가 일방적으로 용암포를 점거하고 요새화하면서 절정에 달한다. 영국은 대한제국이 압록강을 개방하여 러시아의 침투를 견제할 수 있길 바랬지만, 대한제 국은 러일전쟁 발발 시점까지 압록강 개방을 불허하였다. 이로 인해 영국은 대한 제국의 중립국 선언도 의심하게 되고, 러일전쟁 발발 후 일본이 대한제국 정부를 장악하게 되자 일본의 한국 통제를 적극적으로 도왔다. 또한 대한제국의 지체된 근대화에 실망한 영국은 일본의 보호와 지배를 긍정적으로 해석하기도 하였다. 고 종과 한국정부는 영국정부가 대한제국의 독립을 지지해주길 바랬지만, 영국은 일 본의 한국 보호국화를 묵인하는 댓가로 자국의 상업적 이익을 보장받게 되었다.

주제어: 영일동맹, 고종, 대한제국, 구한말, 영국, 영국외교, 조선외교, 영일동맹, 러일전쟁, 조선독립, 조선중립화 
